\title{
Cusp-Field Single-Pole Head Fabricated with Electrodeposited Films
}

\author{
K. Taguchi, T. Yokoshima*,**, M. Uchida, S. Takahashi, K. Yamakawa, K. Ouchi, and T. Osaka**
}

AIT (Akita Research Institute of Advanced Technology, Akita Prefectural R\&D Center), 4-21 Sanuki, Araya, Akita 010-1623, Japan *AIST (National Institute of Advanced Industrial Science and Technology), AIST Tsukuba Central 2, 1-1-1 Umezono, Tsukuba, Ibaraki 305-8568, Japan **School of Science and Engineering, Waseda Univ., 3-4-1 Okubo, Shinjuku-ku, Tokyo 169-8555, Japan

To enhance the write performance of a CF-SPT head, a smaller main pole of Co-Ni-Fe and a finer coil were fabricated by using the electrodeposition method. Fine coils with $2.5 \mu \mathrm{m}$ pitch were obtained by the damascene process. The magnetic domain structure of the $15-\mu \mathrm{m}-$ high and $20-\mu \mathrm{m}$-wide main poles could be controlled by changing their taper angles. A head with a favorable domain except at its tip exhibited stable write performance and no pole erasure. Thus, it was concluded that a control of the magnetic domain was necessary for write heads.

Key words: perpendicular magnetic recording, single-pole head, cusp-field coil, electrodeposited film, magnetic domain structure, pole erasure

\section{めっき法により作製したカスプコイル励磁型単磁極ヘッド}

\author{
田口 香・横島 時彦*,** • 内田 勝 - 高橋 慎吾・山川 清志 · 大内 一弘・逢坂 哲彌** \\ 秋田県産業技術総合研究センター 高度技術研究所，秋田市新屋町字砂奴寄4-21 ( ₹ 010-1623) \\ *独立行政法人産業技術総合研究所, 茨城県つくば市梅園1-1-1 つくば中央第2( \\ **早稲田大学理工学部, 東京都新宿区大久保3-4-1 (ㅍ 169-8555)
}

\section{1. はじめに}

垂直磁気記録用ヘッドとして, 高い記録性能を有するカ スプコイル励磁型単磁極ヘッド1)が提案されている．この ヘッドは，主磁極を挟む $2 つ の$ 補助磁極がシールドとしても 機能するので高い外部磁場而性を有する上，主磁極・補助 磁極・コイルが単純な積層構造になっているので量産性に も優れている．また，主磁極先端部の両側に配置されたコ イルが，ヘッドの高い電流・磁束効率を生み出している. したがって，コイルの小型・高密度化により，このへッド をさらに高性能化することができる，また，主磁極を小型 化することで漏れ磁束の低減による磁束効率の向上も期待 できる. 今回，めっき法を用いて小型化したカスプコイル 励磁型ヘッドを作製する際の主磁極形状と記録特性の関係 について実験的検討を行ったので報告する.

\section{2.ヘッド作製プロセス}

カスプコイル励磁型単磁極ヘッドの構造をFig. 1に示す.この ヘッドは, 下部補助磁極・下部コイル・主磁極・上部コイ ル・上部補助磁極の順に作製する，従来のカスプコイル励磁

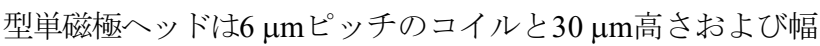
の主磁極により構成されていた。 今回は, コイルピッチと 主磁極を従来の約 $1 / 2$ に型化したへッドを，より微細な構 造の形成に有利であると考えられるめっき法を用いて，以下 の通り作製した。

\section{1 コイル形成}

コイルはダマシン法2)により形成した．初めに絶縁層である $\mathrm{Al}_{2} \mathrm{O}_{3}$ および $\mathrm{SiO}_{2}$ をスパッタ法により成膜する. フォトレジス トによりコイルパターンを形成し, 反応性イオンエッチング

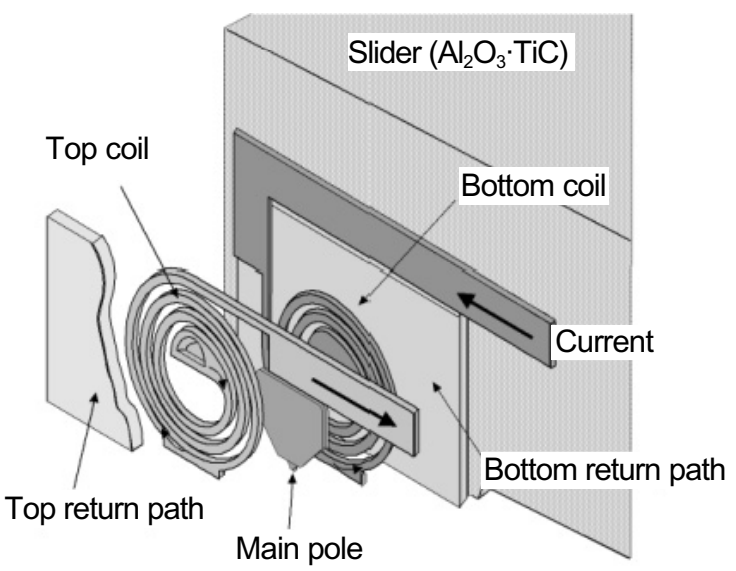

Fig. 1 Schematic view of the CF-SPT head ${ }^{1)}$.

により $\mathrm{SiO}_{2}$ にコイル溝を形成する。なお，このとき $\mathrm{Al}_{2} \mathrm{O}_{3}$ は $\mathrm{SiO}_{2}$ エッチングのストッパーの役割をしている. 反応性ガスと して $\mathrm{CF}_{4}$ に $\mathrm{H}_{2}$ を流量比で $20 \%$ 添加した混合ガスを用い，ガス 圧力 $5 \mathrm{~Pa}$ にエッチングを行った。 めっき用の下地膜として $\mathrm{Cu}(50 \mathrm{~nm}) / \mathrm{Ti}(50 \mathrm{~nm})$ をスパッタ法により形成した後, 電気 めっきにより $\mathrm{Cu}$ 導体部を形成した。 $\mathrm{Cu}$ 導体の形成はダマ シン用硫酸銅めっき浴（添加剤：スルカップESA-21，上村 工業(株)製) にて行い，電流密度は $20 \mathrm{~mA} / \mathrm{cm}^{2}$ とした。コイ ルピッチ $2.5 \mu \mathrm{m}$, 深さ $1 \mu \mathrm{m}$ の溝に厚み $2 \mu \mathrm{m}$ の $\mathrm{Cu}$ 導体をめっ き成膜した後の断面観察SEM(走查型電子顕微鏡) 写真を Fig. 2 に示す. 試料鉛直方向から $55^{\circ}$ の角度より観察した. 幅が約 $1 \mu \mathrm{m}$ のコイル溝に対して欠陥のない埋め込みが行わ れていることが分かる。コイルパッドなど大面積の領域に 対しても同程度の膜厚が形成されていることも確認してい る.また，抵抗率に関しても $2 \mu \Omega \cdot \mathrm{cm}$ であり，膜密度として も十分な值が得られていると考える。 


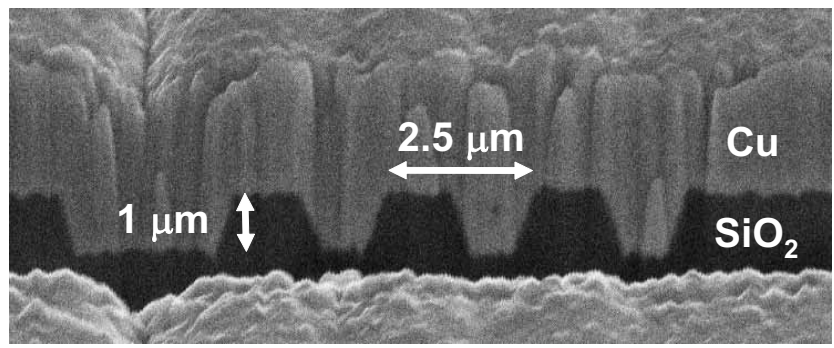

Fig. 2 Cross-sectional view of a coil.

\section{2. $2 \mathrm{Co}-\mathrm{Ni}-\mathrm{Fe}$ 軟磁性薄膜の形成}

主磁極及び上部・下部補助磁極には $\mathrm{Co}_{63} \mathrm{Ni}_{13} \mathrm{Fe}_{24}$ めっき薄膜 3)を用いた。 Table 1に浴組成および成膜条件を示す．成膜

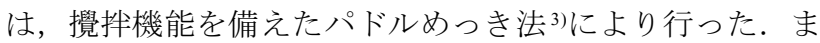
た，誘導異方性を付与寸るため $100 \mathrm{Oe} の$ 磁界を主磁極の幅 方向に印加しながら成膜している。主磁極は反磁界抑制に 有効と言われているフレームめっき法4)を用いて, 以下の 手順で形成した。 下地膜として $\mathrm{Cu}(100 \mathrm{~nm}) / \mathrm{Ti}(10 \mathrm{~nm})$ 膜をス パッタ法により成膜する。その上に，フォトリソグラ フィーにより幅 $1 \mu \mathrm{m}$, 高さ $0.4 \mu \mathrm{m}$ のレジストフレームを形 成する，酸による表面処理を行った後，200 nm厚のCo-NiFe膜をめっきする．Fig.3にフレームパターンを有する 200 $\mathrm{nm}$ 厚のCo-Ni-Feめつき膜の磁化曲線を示す. 飽和磁束密度 $B_{S}$ が $20 \mathrm{kG}$, 異方性磁界 $H_{k}$ が $20 \mathrm{Oe}$ であり，困難軸方向の 抗磁力 $H c$ が $2 \mathrm{Oe}$, 角型比 $S$ が 0.2 の一軸異方性が付与され ていることが確認できた。下部および上部補助磁極の膜厚 は1 $\mu \mathrm{m}$ とたが，そのときのHcとSはそれぞれ 1 Oeと 0.1 以 下であった。

今回, 主磁極の高さを従来の半分の $15 \mu \mathrm{m}$ とし, 磁路長を 短くした．幅が高さと同じ場合には容易軸方向に平行な磁 壁を持たない磁区構造が現れており，主磁極として不適当 であることが分かった ${ }^{5}$. そこで, 形状異方性効果と逆磁歪 効果による実効的な異方性を増加させて磁区構造を改善す

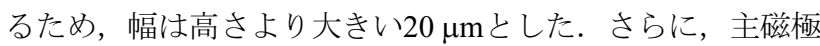
の先端絞込み角度 $\theta$ を $45 \mathrm{deg}$. および $14 \mathrm{deg}$. の 2 種類のヘッ

Table 1 Bath composition and plating conditions for electrodeposited Co-Ni-Fe films.

\begin{tabular}{|l|c|}
\hline Chemicals & Concentration $\left(\mathrm{mol} / \mathrm{dm}^{3}\right)$ \\
\hline $\mathrm{H}_{3} \mathrm{BO}_{3}$ & 0.4 \\
\hline $\mathrm{NH}_{4} \mathrm{Cl}$ & 0.28 \\
\hline $\mathrm{CoSO}_{4} 7 \mathrm{H}_{2} \mathrm{O}$ & 0.064 \\
\hline $\mathrm{NiSO}_{4} 6 \mathrm{H}_{2} \mathrm{O}$ & 0.2 \\
\hline $\mathrm{FeSO}_{4} 7 \mathrm{H}_{2} \mathrm{O}$ & 0.011 \\
\hline $\mathrm{SDS}$ & $10 \mathrm{ppm}$ \\
\hline $\mathrm{pH}$ & 2.8 \\
\hline Current density & $20 \mathrm{~mA} / \mathrm{cm}^{2}$ \\
\hline Agitation speed & $144 \mathrm{cpm}$ \\
\hline Bath temperature & $18-21^{\circ} \mathrm{C}$ \\
\hline Counter electrode & $\mathrm{Co}$ plate \\
\hline Magnetic field & 100 Oe \\
\hline $\begin{array}{l}\text { Underlayer } \\
\text { / substrate }\end{array}$ & $\begin{array}{c}\text { Cu/Ti/glass } \\
(1 \text { inch square })\end{array}$ \\
\hline
\end{tabular}

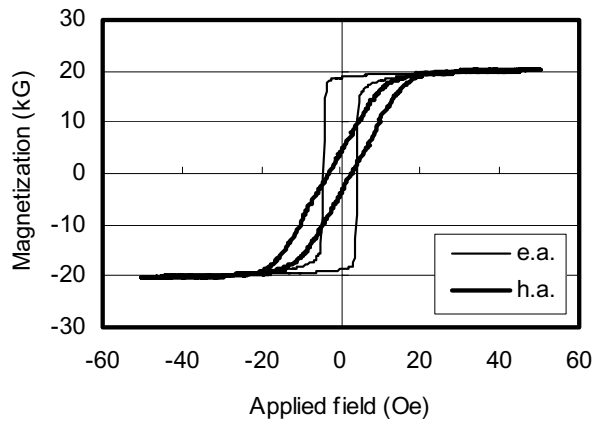

Fig. 3 M-H loop for 200-nm-thick Co-Ni-Fe electrodeposited film.

\section{ドを検討した。}

主磁極の先端絞込み角度 $\theta$ の異なる主磁極の MFM(磁気力 顕微鏡)像をFig.4に示す。 $\theta$ が45 deg.の主磁極にはほとんど エッジに平行な磁区しか観察されず，主磁極絞込み部に は，縦に走る磁壁が観察される。それに対して， $\theta$ ぞ $14 \mathrm{deg}$. の主磁極絞込み部には，幅方向に平行な磁化ベクトルを有 する大きな磁区が現れ，縦に走る磁壁は観察されない。主 磁極の先端絞込み角度を小さくすることは, 少なくとも主 磁極の幅広部の磁区制御には有効な手段であることが確認 された。主磁極先端部の磁区構造に関しては, 今後, 詳細 な検討を要すると考えている.

\section{3 めっき膜を適応したカスプコイル励磁型ヘッドの作製}

以下にFig. 1の構造を有するカスプコイル励磁型単磁極へッ ドの作製手順について述べる．基板としてはへッド磨耗が少 ないと考えられる $\mathrm{Al}_{2} \mathrm{O}_{3}$ - $\mathrm{TiC}$ 基板( $1 \mathrm{~mm}$ 厚)を用いた。初めに $100 \mu \mathrm{m}$ 角の下部補助磁極部分として前述のCo-Ni-Fe膜をつ レームめつき法により厚み $1 \mu \mathrm{m}$ 形成する。この場合のフ レーム幅は $3 \mu \mathrm{m}$, 高さ約 $1.2 \mu \mathrm{m}$ とた。 フレームめっき 後, レジストにより磁極部分を覆う。磁極周囲の余分な磁 性膜をイオンミリング法により除去し，さらにレジストを

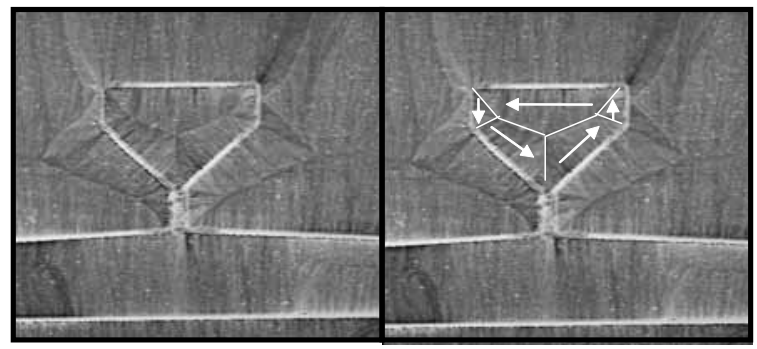

(a) $\theta=45 \mathrm{deg}$.

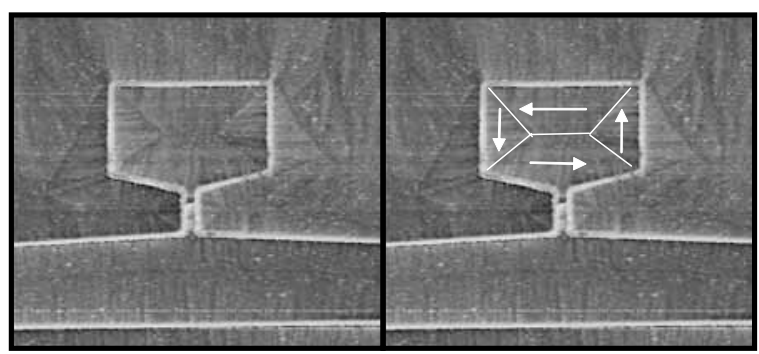

(b) $\theta=14 \mathrm{deg}$.

Fig. 4 MFM images of the main pole core with different taper angles. Schematic magnetic domains are shown on the right. 
除去することで補助磁極形状が形成される，なお，この方 式の場合, レジストフレーム直下の $\mathrm{Cu} / \mathrm{Ti}$ 下地層が除去でき ないことになるが，非磁性材料であるため, ヘッドの記録 性能には影響しないと考えられる. 続いて, 磁極周囲の絶 縁層として $\mathrm{Al}_{2} \mathrm{O}_{3}$ を成膜し, 平坦化研磨を行うことで磁極上 $の \mathrm{Al}_{2} \mathrm{O}_{3}$ を除去する. 続いて下部補助磁極と下部コイル間の 絶縁層 $\mathrm{Al}_{2} \mathrm{O}_{3}$ を $0.5 \mu \mathrm{m}$ おびコイル間の絶縁層 $\mathrm{SiO}_{2}$ をスパッ 夕法により形成する。コイル形成については前述の通りダ マシン法により形成する, 即ち, 導体Cu膜をめっき法によ り成膜した後, 平坦化研磨により不要な $\mathrm{Cu}$ 膜の除去を行 う。このとき， $\mathrm{SiO}_{2}$ とCu間の段差は $40 \mathrm{~nm}$ 以下であった。 下 部コイルと主磁極間の絶縁層 $\mathrm{Al}_{2} \mathrm{O}_{3}$ をスパッタ法により 0.5 $\mu \mathrm{m}$ 成膜した後, 前述のフレームめっき法により主磁極を形 成する. 補助磁極の形成と同様に主磁極部をレジストで保 護し, ケミカルエッチングにより不要な磁性膜およびCu下 地層を除去する. その後, レジストを除去し，イオンミリ ング法によりTi下地層の除去を行う。この際, 主磁極膜も 同時にエッチングを行うことになるが，あらかじめ膜減り 分を考慮して主磁極を厚くしている. また, 膜面の平坦性 は記録磁化転移形状に直接影響を及ぼすが，今回の成膜条 件によるフレームめっきでは膜表面形状の $\mathrm{AFM}$ (原子間力 顕微鏡)観察においてトラック中央部分の盛り上がりなどの 平坦性の劣化は見られていない, 主磁極部を形成後の顕微 鏡観察写真をFig.5に示寸. 最外周のコイル幅の半分程度まで 摺動面の研磨を行うことで, 先端励磁が可能な構造となって いる.この後の工程は再び絶縁層 $\mathrm{Al}_{2} \mathrm{O}_{3}$ を文, 下部コイル と逆巻に上部コイルを形成する。 そして, 絶縁層を介して 上部補助磁極を形成し, 保護膜を形成して完成する。作製 したヘッドの緒元をTable 2に示す. 摺動面の機械加工を行 い, コンタクト方式で記録するための 3 点パッドを摺動面に 形成後，平行リンクサスペンションに取り付けた.

\section{3. 主磁極形状と記録再生特性}

2.2節で述べたように, 磁区構造の観点からは主磁極の先端 絞込み角度 $\theta$ が $14 \mathrm{deg}$. と小さい方がよりヘッド主磁極に適

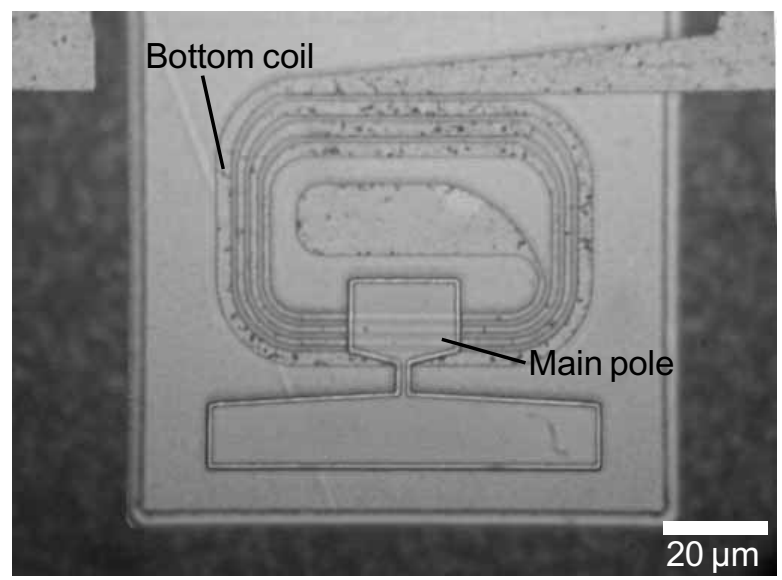

Fig. 5 Structure of a CF-SPT head with electrodeposited films.
Table 2 Head specification.

\begin{tabular}{l|c}
\hline Main pole material & Co-Ni-Fe \\
\hline$B_{s}$ & $20 \mathrm{kG}$ \\
\hline Main pole thickness & $0.2 \mu \mathrm{m}$ \\
\hline Track width & $1 \mu \mathrm{m}$ \\
\hline Throat height & $1.5 \mu \mathrm{m}$ \\
\hline Return path material & Co-Ni-Fe \\
\hline Return path thickness & $1 \mu \mathrm{m}$ \\
\hline Number of coils & 4 turns \\
\hline
\end{tabular}

した構造であると考えられる。この磁区構造の違いが記録 特性に与える影響について調べるため, $\theta$ が $14 \mathrm{deg}$. と $45 \mathrm{deg}$. のヘッドについて入出力特性を測定した. その結果を Fig.6 に示す. 再生には市販の浮上型GMRヘッド $\left(T_{w r}=0.23 \mu \mathrm{m}\right.$, $\left.G_{S}=0.075 \mu \mathrm{m}\right)$ を用い, 記録と再生を分離して行った。ヘッ ドー媒体間相対速度は $10 \mathrm{~m} / \mathrm{s}$ とした。媒体として $50 \mathrm{~nm}$ 厚の 記録層を有する $\mathrm{Co}-\mathrm{Cr}$ 系二層膜垂直記録媒体 $\left(H_{C}=3.4 \mathrm{kOe}\right.$, $\left.H_{S}=8 \mathrm{kOe}, S Q=0.74\right)$ を用いた．両者の記録感度にわずかな 違いが見られるものの，いずれのへッドにおいても，今回 用いた媒体を十分に飽和記録できていることが分かる。ま た，記録密度特性についても，Fig.7に示すように，両ヘッ ドで大きな違いは見られず, 今回の測定周波数範囲 $(f \sim 100$

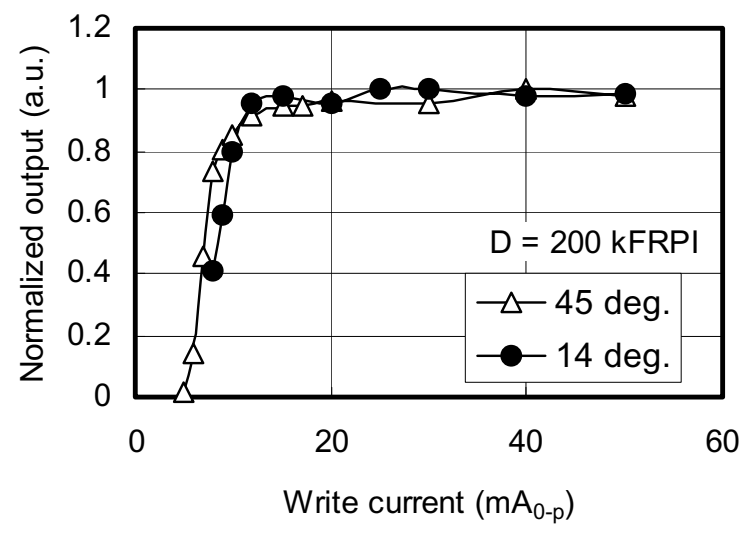

Fig. 6 Saturation curves of the CF-SPT heads with different taper angles of the main pole.

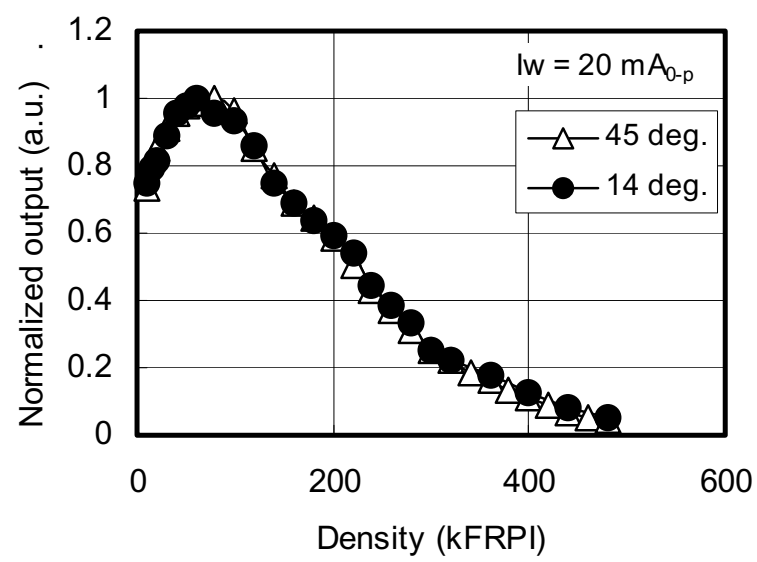

Fig. 7 Roll-off curves of the CF-SPT heads with different taper angles of the main pole. 


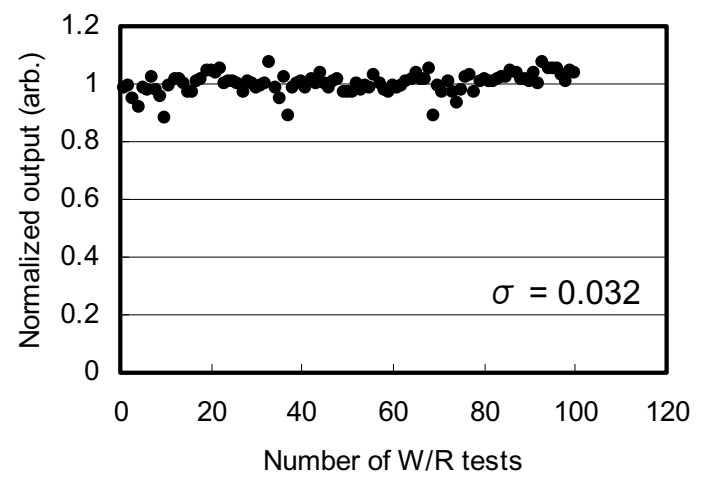

(a) $\theta=45 \mathrm{deg}$.

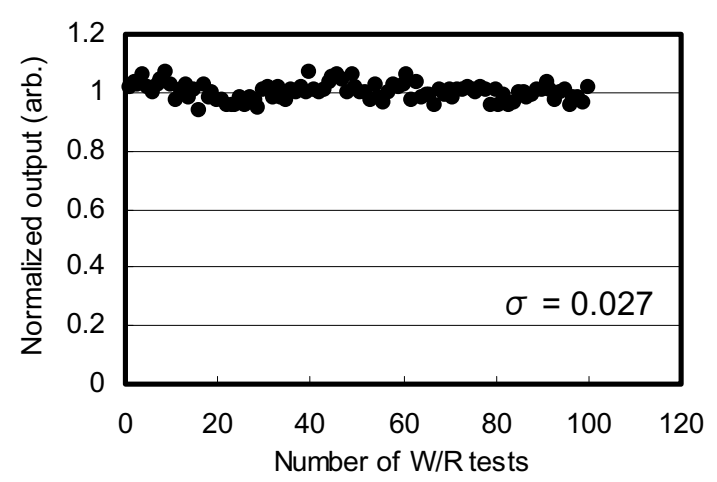

(b) $\theta=14$ deg.

Fig. 8 Deviation of the reproduced output in every dc-erase/ writeoperation.

MH)では，磁区構造の違いの記録特性への影響は認められ なかった。

次に, 記録特性の安定性を調べるため, $\theta$ が異なる 2 種類 のヘッドについて, 記録ヘッドにより $50 \mathrm{~mA}$ で直流消去後, $40 \mathrm{kFRPI}, 20 \mathrm{~mA}_{0-\mathrm{p}}$ の信号を記録し, 再生出力を測定する一 連の動作を 100 回繰り返し行った。その結果を, Fig.8 に示 す. 縦軸は平均值で規格化した出力, 横軸は記録再生操作 の回数である.いずれのヘッドにおいてもほぼ土 $10 \%$ 以内 の出力変動に収まっているものの, 標準偏差 $\sigma$ としては, $45 \mathrm{deg}$.のヘッドでは 0.032 に対し, $14 \mathrm{deg}$.のヘッドでは 0.027 と減少し,これは $15 \%$ 程度出力変動が小さくなったことを 意味している.このことから，主磁極絞込み部に現れてい た縦方向に走る磁壁も出力変動の原因のひとつであると考 えられる。

また,ヘッドの帯磁による影響を調べるため,ヘッドLoad 状態における再生出力の減衰を測定した，記録へッドによ り直流消去を行った後, $40 \mathrm{kFRPI}, 20 \mathrm{~mA}_{0-\mathrm{p}}$ の信号を記録し, 記録へッドをLoad 状態での再生出力の時間变化を測定し た. 主磁極の先端絞込み角度 $\theta$ が異なる 2 種類のヘッドに ついて測定した結果をFig.9に示す. 評価に用いた媒体は $S Q$ が1以下であるため, 縦軸の出力減衰を, Un-load状態での再 生出力で規格化することにより, 媒体自身の熱減磁による 減衰分を排除している。 $\theta$ が $45 \mathrm{deg}$. のヘッドにおいては約

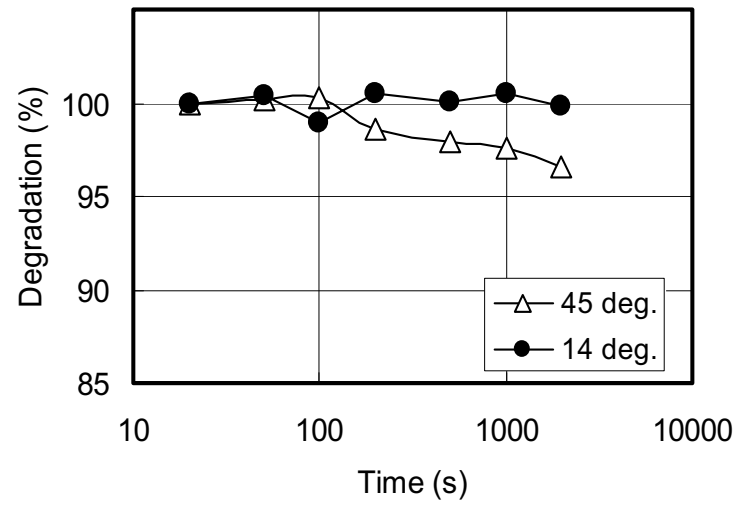

Fig. 9 Degradation of the reproduced output by the head load state. Output signals were normalized by the output for the head un-load state at every measurement.

$2.5 \% /$ decade の出力減衰が観測されたが， $\theta$ が $14 \mathrm{deg}$.のヘッ ドにおいては, ヘッドに起因する再生信号の減衰はほとん ど見られなかった。

以上の結果から，主磁極の先端絞込み角度を小さくする ことで, 記録特性の安定性や帯磁の問題を改善できること が分かった。これらは，主磁極絞込み部の磁区制御の効果 であり,さらに, 幅 $1 \mu \mathrm{m} ・$ 高さ $1.5 \mu \mathrm{m}$ の主磁極先端部の磁 化ベクトルが主磁極絞込み部を反映してトラック幅方向を 向いている可能性があることを推測させる結果と考えられ る.この効果が，さらに小さな主磁極先端部でも適用でき るかは, 今後の検討を要する.

\section{4. おわりに}

カスプコイル励磁型単磁極ヘッドをさらに高性能化するた め，めっき法を用いて主磁極及びコイルを小型化したヘッド を作製した．磁気ヘッドの記録特性は主磁極絞込み部の磁区 構造の影響を受けることが分かった。したがって，記録へッ ドにおいては少なくとも主磁極幅広部の磁区制御が重要であ ると考えられる.また，この部分の磁区制御には主磁極の先 端絞込み角度を小さくすることが有効であり，磁区構造に起 因する問題を改善できる一手法であることが分かった。

謝辞 日頃, ご指導・ご鞭撻を賜りますAIT 名誉所長 岩崎俊 一 東北工業大学学長に深謝致します. 媒体を作製したAIT 有 明順上席研究員に感謝寸る.本研究の一部は文部科学省科学技 術振興調整費「ナノ界面制御による磁気記録材料の創製」の 研究助成を受けて行われた。関係の方々に謝意を表す。

\section{Reference}

1) K. Ise, et al., IEEE Trans. Magn., 36, pp.2520-2523 (2000)

2) E. J. O'Sullivan, et al., IBM J. Res. Dev., 42, 607 (1998)

3) T. Osaka, et al., Nature, 392,796(1998)

4) J. V. Powers, L, T. Romankiv, US. Patent, 3652442(1972)

5) T. Yokoshima, et al., Proc. the 2005 IEICE general conf., C-7-1(2005)

2005 年 10 月 19 日受理, 2006 年 2 月 21 日採録 